\title{
Uncovering the Students' Mathematical Concept Understanding Ability: A Based Study of Both Students' Cognitive Styles Dependent and Independent Field in Overcoming the Problem of 3D Geometry
}

\author{
Sudirman ${ }^{1}(*)$, Aloisius Loka Son ${ }^{2}$, Rosyadi $^{3}$, Rizkiah Nurul Fitriani ${ }^{4}$ \\ ${ }^{1,3,4}$ Universitas Wiralodra, Jln. Ir. H. Juanda Km 3 Indramayu, Jawa Barat, Indonesia \\ ${ }^{2}$ Universitas Timor, Sasi, Kota Kefamenanu, Kabupaten Timor Tengah Utara, Nusa \\ Tenggara Timur, Indonesia
}

\section{Received: June 09, 2019 \\ Revised: $\quad$ March 02, 2020 \\ Accepted: March 20, 2020}

\begin{abstract}
The present study aims at uncovering mathematical concept understanding ability in solving the problem of 3D geometry from the perspective of both cognitive styles dependent and independent field. For the instrument, this study adopts Group Embedded Figure Test, observation worksheet, test, interview, and documentation. In dealing with data analysis, it relies on qualitative analysis consisting of data reduction, data display, and conclusion drawing. Based on the investigation, it could be inferred that the students with the cognitive dependent field could solve the problem with 3D geometry; however, they still need some improvements to realize a proper way in using such method. On the other hand, the students with cognitive independent field, they could correctly operationalize the 3D geometry concept to solve the same problem. In addition, this study also recommends to minimize the problem above; the teacher is supposed to give proportional distribution in implementing either individual or group task.
\end{abstract}

Keywords: Field dependent, Field Independent, Understanding of mathematical concepts, 3D Geometry

(*) Corresponding Author:

How to Cite: Sudirman, Son, A.L, Rosyadi \& Fitriani, R.N. (2020). Uncovering the students' mathematical concept understanding ability: A based study of both students' cognitive styles dependent and independent field in overcoming the problem of 3D geometry. Formatif: Jurnal Ilmiah Pendidikan MIPA, 10 (1): 1-12. http://dx.doi.org/10.30998/formatif.v10i1.3789

\section{INTRODUCTION}

The ability to understand mathematical concepts is an essential foundation for building high-level mathematical competency (Sumartini \& Priatna, 2018). It is because, the nature of mathematics as an abstract and logical science, and since many things in the universe that have not been revealed through mathematics (Ali \& Reid, 2012) and the purpose of studying various mathematical concepts is to solve problems(Minarni, Napitupulu, \& Husein, 2016). According to the Principle of the Standard of School Mathematics (NCTM, 2000), the purpose of students learning mathematics is to develop and deepen their understanding of concepts and the relationship of mathematics in making, comparing, and using various representations.

However, if we look deeper into the mathematical concept competency of students in Indonesia, it is still relatively low. It can be proven from the results of TIMSS and PISA shown in Figures 1 and 2 below. 


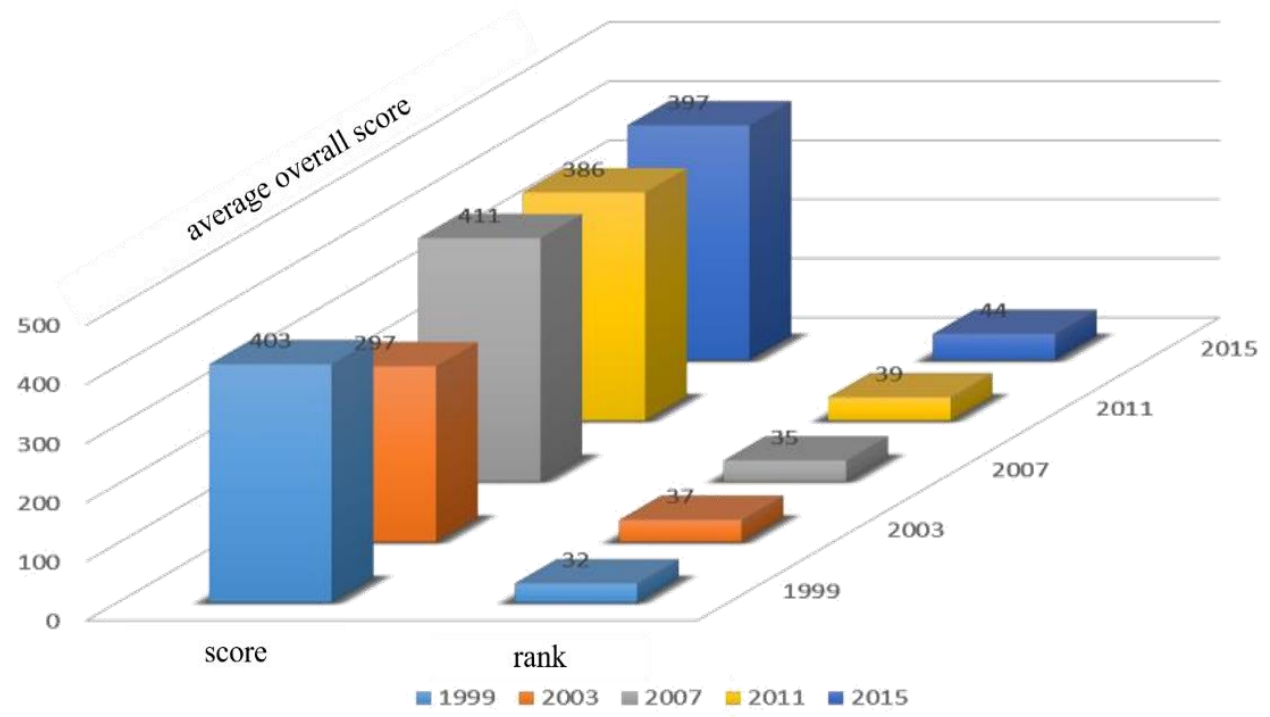

Figure 1. Mathematical Abilities based on PISA (OECD, 2000; OECD, 2003; OECD, 2006; OECD, 2012; OECD, 2015)

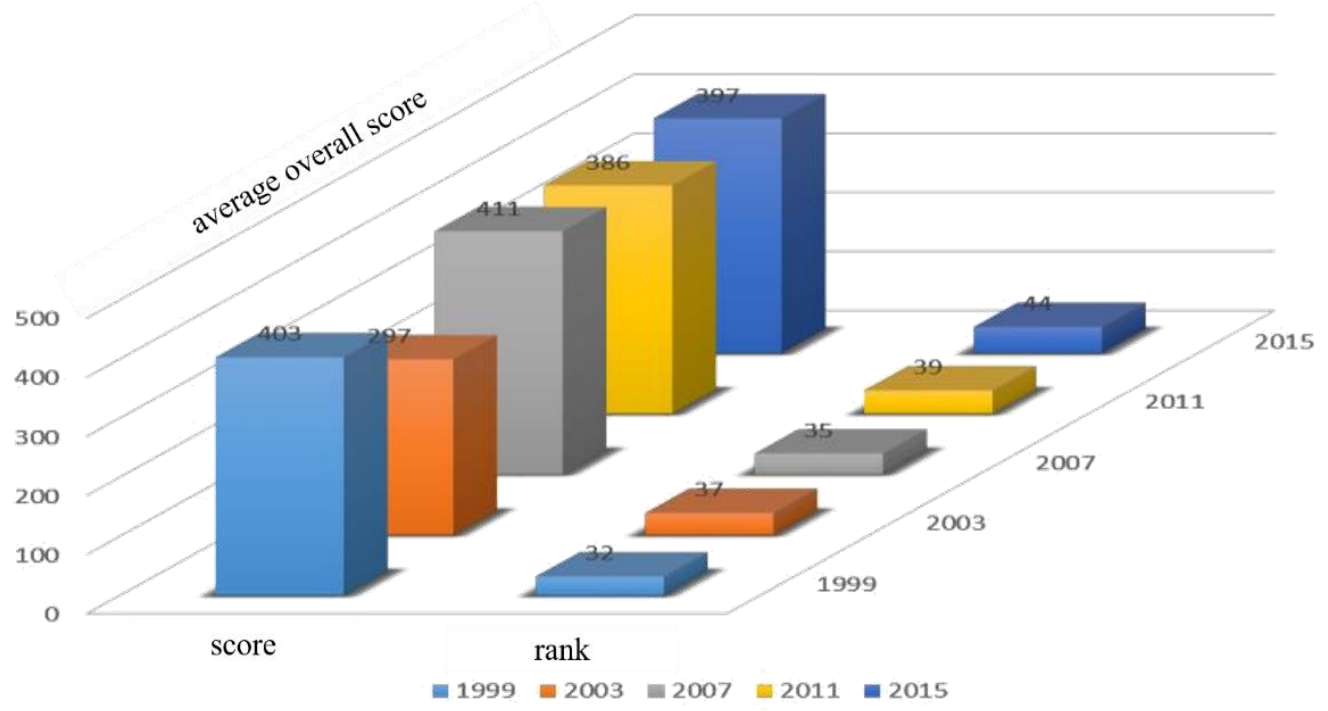

Figure 2. Quality of Mathematical Ability based on TIMSS (IEA, 1999; IEA, 2004, IEA, 2008; IEA, 2011; TIMSS, 2015).

The PISA and TIMSS results showed that the average score of students in Indonesia is always below the overall average rating and Indonesia still occupies the lowest position of the 10 (ten) countries that are included in the test.

There are many factors contributed to students competencies in mathematics, such as school origin (Sudirman, 2016), teacher's reflective thinking capability (Nuriadin, Kusumah, Sabandar, \& Dahlan, 2015), the use of learning models (Lambertus, 2016) and many more. Therefore, one of the important things for teachers to consider in teaching is the students learning experience and styles so that their mathematical thinking processes can be improved (Nuriadin et al., 2015). These differences occur due to students different 
characteristics leading to students differences in the thinking process. These differences are often referred to as cognitive styles (cognitive styles).

Students who have Field Dependent cognitive style tend to think thoroughly, not analytically and systematically, easily influenced by their environment, not independent, lack of confidence in one's abilities, and prefer social sciences (Karaçam, 2015). Whereas students with Independent Field cognitive style tend to think analytically and systematically, not easily influenced by the environment, independent, believe in one's own abilities, and prefer natural sciences (Onyekuru, 2015). However, according to Wulandari (2017: 97), the grouping of cognitive styles does not mean that one cognitive style is better than the other. Cognitive styles grouping enables us to identify differences in the way of thinking between the two.

Based on investigations by researchers at the school, several facts were found, including those related to national exam results in the last three years. The average percentage of math test results in the last three years; in 2014/2015 the number of examinees was 121 students with an average score of 49.8\%, in 2015/2016 the number of examinees was 142 students with an average score of 51.6\%, and in 2016/2017 the number of examinees was 148 students with an average score of 55\% (School Administration Office, 2018) respectively. The data clearly showed the difference of students' ability to conceptual understanding each year. Researchers also briefly interviewed mathematics teachers how well their students understand mathematical concepts given, and it is concluded that they have a pretty good learning comprehension. However, each student has a different learning comprehension level due to their characteristics differences.

Furthermore, there are several relevant studies in this field, such as (1) Agoestanto, Sukestiyarno, \& Rochmad (2016) on analysis of creative thinking ability in terms of cognitive style. (2) Wijayanti, Safitri, \& Raditya (2018) on study of students understanding on the concept of limits in terms of interpersonal learning styles. (3) Waedi, Winarso, \& Izzati (2017) on a comparison of students' understanding of mathematical concepts in terms of cognitive style between independent field and dependent field.

\section{METHODS}

Based on the problem studied, the research can be classified as qualitative research. This research was conducted at one of the Tsanawaiyah Madrasah schools in Indramayu. The research subject was determined by administering a GEFT cognitive style test. The GEFT test was conducted over the VIII A grade students as the most favored classroom at the school. From the test result, students who have the most definite tendency towards each type of cognitive style were selected. Therefore, there were four research subjects obtained, consisting of two students from Field Dependent cognitive style and two students Independent Fieldcognitive style. In this study, the researcher used observation, tests, interviews, and documentation data collection techniques.

The test instrument used were the Group Embedded Figure Test (GEFT) and mathematical concept comprehension test. The GEFT instrument consists of 3 parts, with a total of 25 questions. The first part of the GEFT test consists of 7 items, while the second and the third parts consist of 9 item each. The first part is an exercise while the scores are calculated from the second and the third parts of the GEFT test. The GEFT test was administered for 20 minutes. Each correct answer was scored 1 while the wrong answer was scored 0. Results of the second part and the third part of the GEFT test were then combined. Students with 0-11 score were grouped into Field Dependent cognitive style, while students with 12-18 score were grouped into the Field Dependent cognitive style. 
Then, the four research subjects were given 5 questions to test their comprehension of the concept of volume and surface area of cubes and bars which have been tested at the IX A grade. Furthermore, the researcher interviewed the four research subjects. Test and interview were carried out on different schedules to prevent subjects from giving similar answers Research instruments were developed by taking mathematical concept comprehension indicators into account. There were only 3 indicators used out of the 7 indicators available for the existing question, namely developing the necessary/sufficient requirements for concept comprehension, using, utilizing, and choosing specific procedure or operations, and applying concepts or algorithms comprehension in problem-solving process.

\section{RESULTS \& DISCUSSION}

\section{Results}

The following will describe the overall research results obtained through observation, tests, interviews, and documentation based on three indicators by describing Field Dependent students and Field Independent students.

\section{Description of Understanding Ability Understanding Mathematical Concepts of Students with Cognitive Style Field Dependent}

2. Sebuah balok memiliki lebar dan tinggi yang sama. Volume balok tersebut adalah $1.053 \mathrm{~cm}^{3}$. Panjang balok $13 \mathrm{~cm}$. Tentukan tinggi balok!

Figure 3.a. Problem Number 2

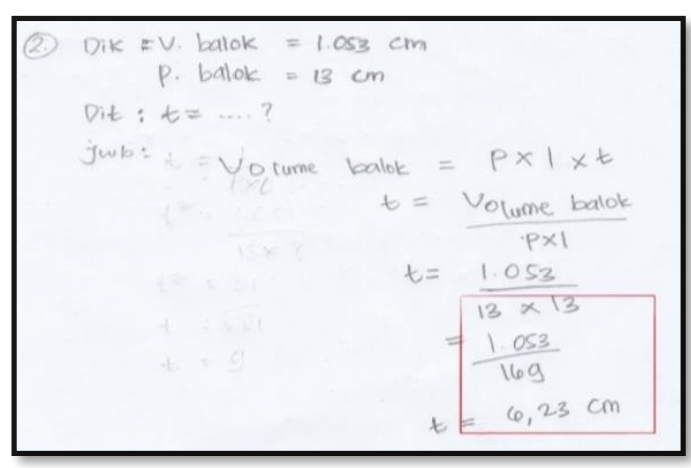

Figure 3.b. Student Answers FD 1 Regarding Problem Number 2

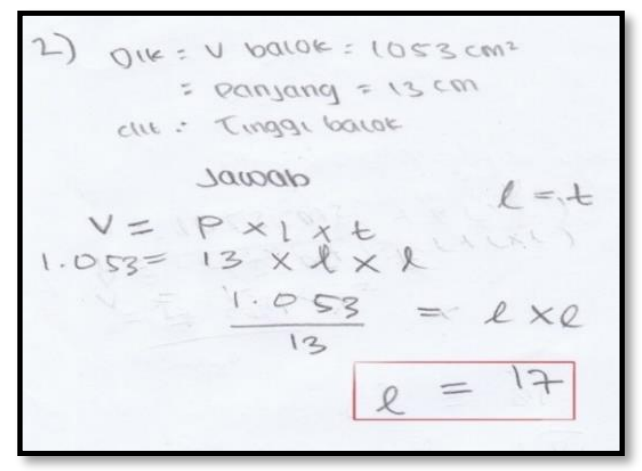

Figure 3.c. Student Answers FD 2 Towards Problem Number 2

Students with Field Dependent cognitive style are less able to develop sufficient requirements/conditions needed to understand the given concept when working on question two. The student with Field Dependent cognitive style find difficulties to get ideas, and tend to be more silent, and struggles to figure out solutions to existing problems or commonly called "stuck". Hence, they are less able to develop an understanding of any given concept. 
3. Diketahui panjang balok tiga kali dari tingginya. Tinggi balok $3 \mathrm{~cm}$ dan lebar balok $5 \mathrm{~cm}$. Hitunglah volume balok tersebut!

Figure 4.a. Problem Number 3

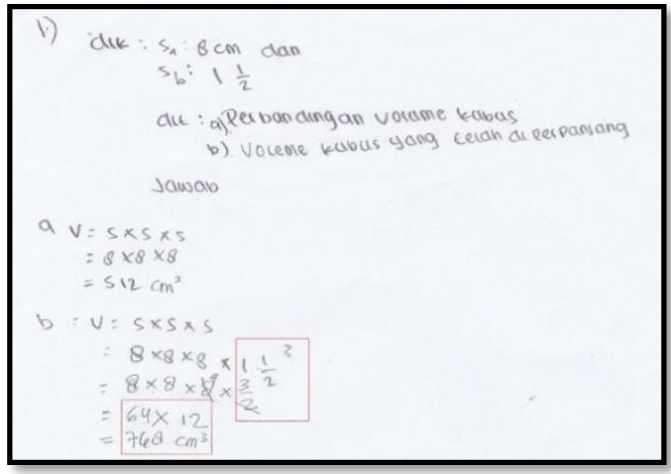

Figure 4.b. Student Answers FD 1 Regarding Problem Number 3

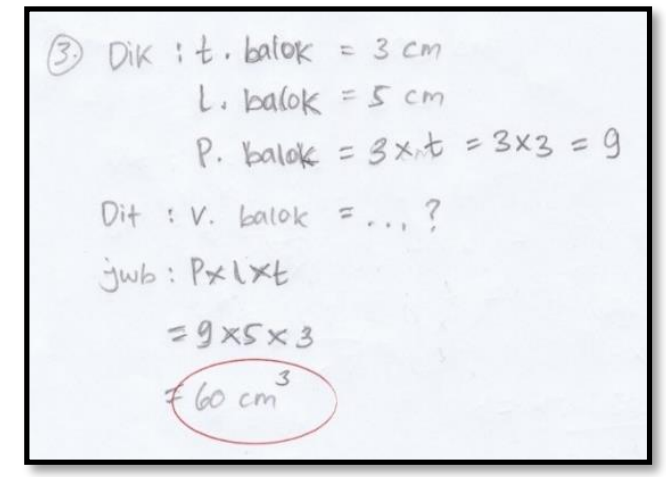

Figure 4.b. Student Answers FD 1 Regarding Problem Number 2

Students with Field Dependent cognitive style can use, utilize, and choose certain procedures or operations when working on questions number 1, 3, and 4. From the study results, it appears that students with Field Dependent cognitive style made mistakes with the final result. Students from both groups were able to determine the known and asked value. However, students with Field Dependent cognitive style made mistakes due to lack of concentration, lack of confidence in their understanding of the concepts given, and less able in filtering information obtained, so that they were easily influenced by the surrounding environment.

5. Sebuah aquarium berbentuk balok memiliki panjang $7 \mathrm{~cm}$ dan lebar $5 \mathrm{~cm}$ Jika aquarium terisi air $\frac{5}{7}$ bagian dan diketahui luas permukaan aquarium $214 \mathrm{~cm}^{3}$. Tentukan berapa volume air di dalam aquarium tersebut!

Figure 5.a. Problem Number 5

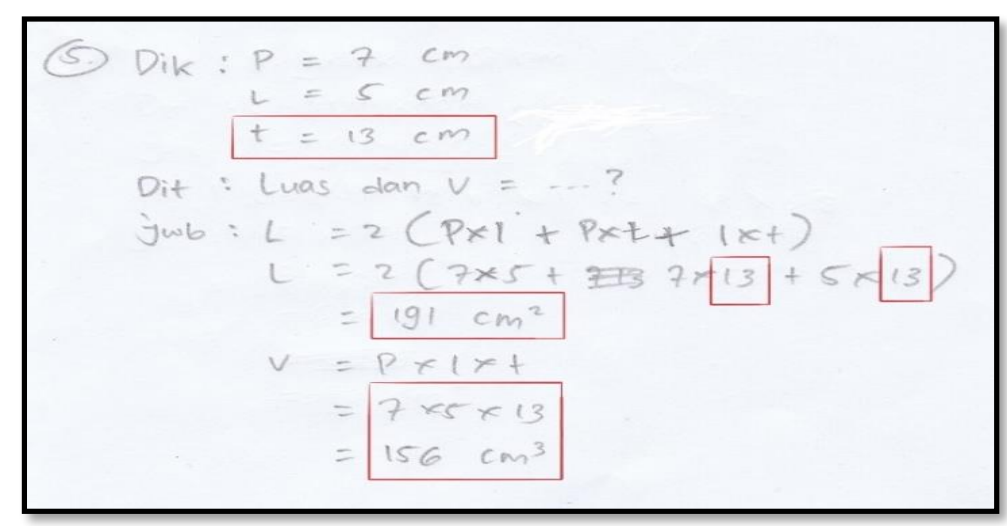

Figure 5.b. Student Answers FD 1 Regarding Problem Number 5 


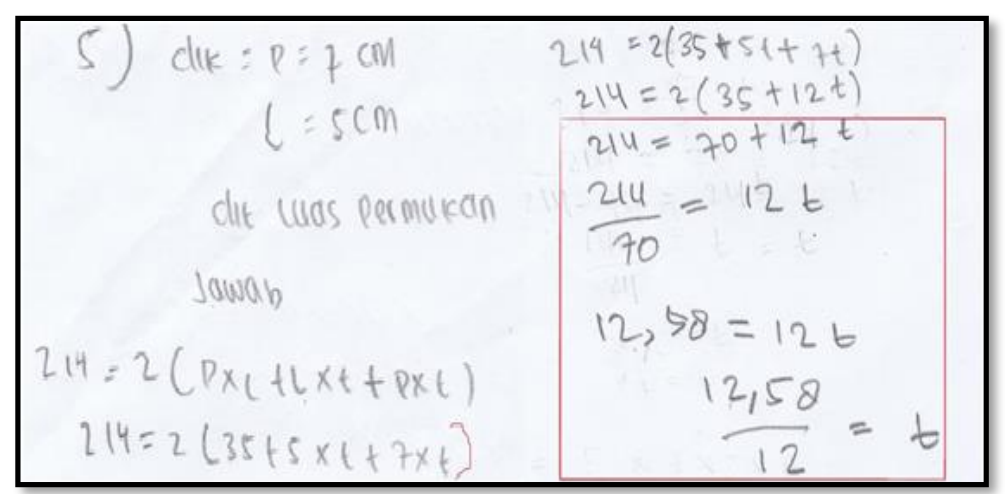

Figure 5.c. Student Answers FD 2 Regarding Problem Number 5

The student with Field Dependent cognitive style was less able to apply their understanding of concepts or problem-solving algorithm when working on question number 5 . The student with Field Dependent cognitive style was less able to associate their understanding of concepts with real life, unable to think complexly, tended to think globally, less able to analyze well. As a result, they can not answer question number 5 correctly.

\section{Description of Understanding Ability Understanding Mathematical Concepts of Students in Cognitive Style Independent Field}

2. Sebuah balok memiliki lebar dan tinggi yang sama. Volume balok tersebut adalah $1.053 \mathrm{~cm}^{3}$. Panjang balok $13 \mathrm{~cm}$. Tentukan tinggi balok!

Figure 6.a. Problem Number 2

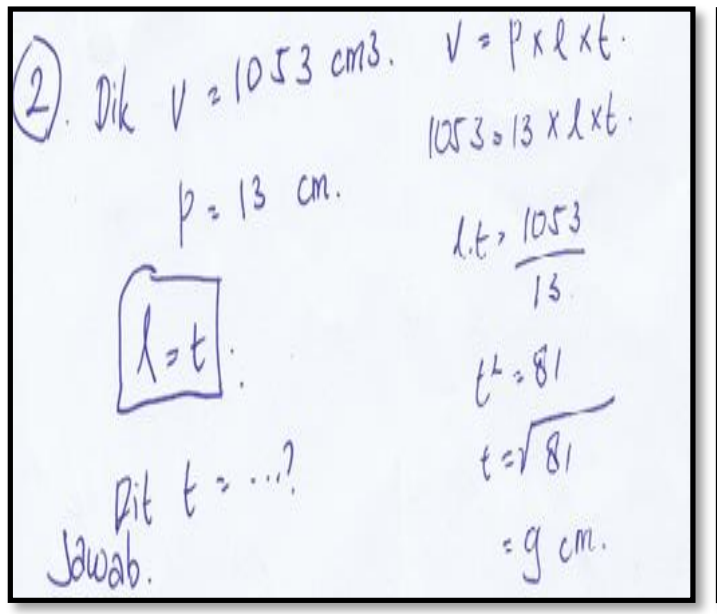

Figure 6.b. FI Student Answers 1 to Problem Number 2

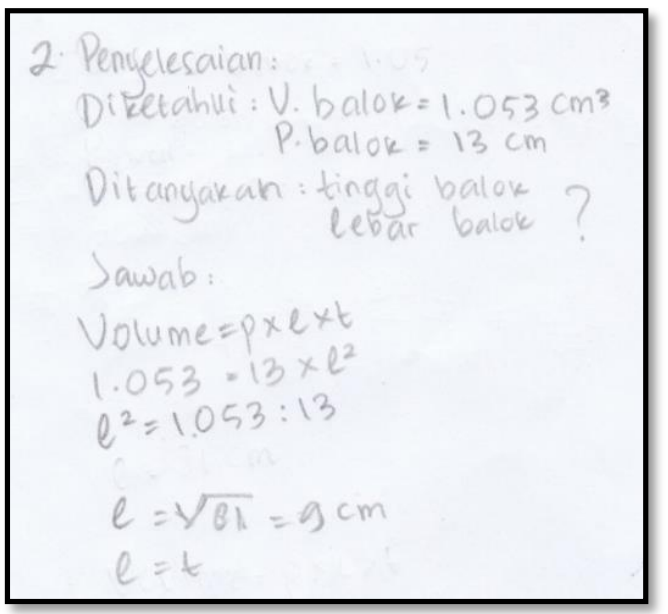

Figure 6.c. FI Student Answers 2 to Problem Number 2

The student with Independent Field cognitive style can develop necessary conditions to comprehend of the concept when working on question number 2. Student with Independent Field cognitive style can find a solution after remembering of concepts they comprehended and can develop their understanding of the concepts. 
3. Diketahui panjang balok tiga kali dari tingginya. Tinggi balok $3 \mathrm{~cm}$ dan lebar balok $5 \mathrm{~cm}$. Hitunglah volume balok tersebut!

Figure 7.a. Problem Number 3

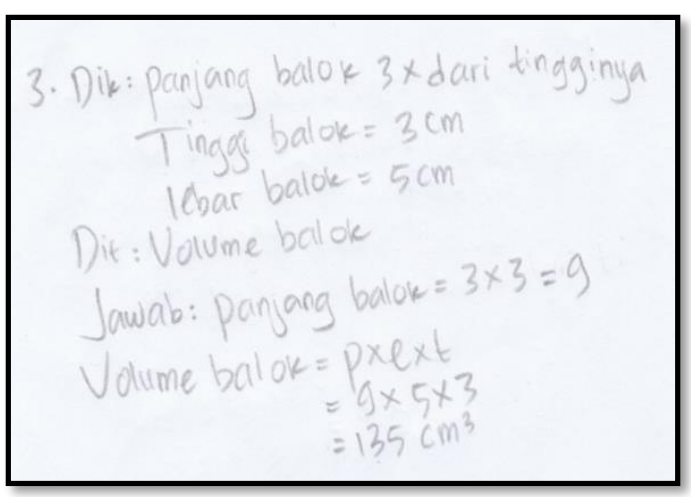

Figure 7.b. FI Student Answers 1 to Problem Number 3

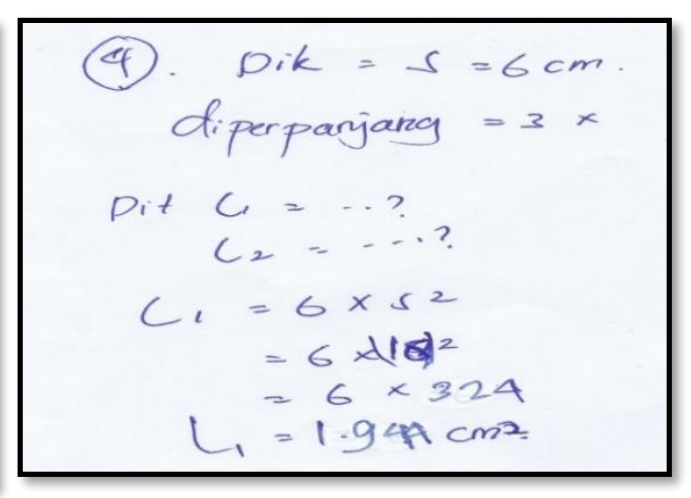

Figure 7.c. Student Answer DI 1 to Problem Number 4

Student with Independent Field cognitive style can use, utilize, and choose certain procedures or operations contained in questions number 1,3, and 4. Students with Independent Field cognitive style can easily process information contained in the question, filter the information given, and they can relate their understanding of the concept to the question given independently without being influenced by others.

5. Sebuah aquarium berbentuk balok memiliki panjang $7 \mathrm{~cm}$ dan lebar $5 \mathrm{~cm}$. Jika aquarium terisi air $\frac{5}{7}$ bagian dan diketahui luas permukaan aquarium $214 \mathrm{~cm}^{3}$. Tentukan berapa volume air di dalam aquarium tersebut!

Figure 8.a. Problem Number 5

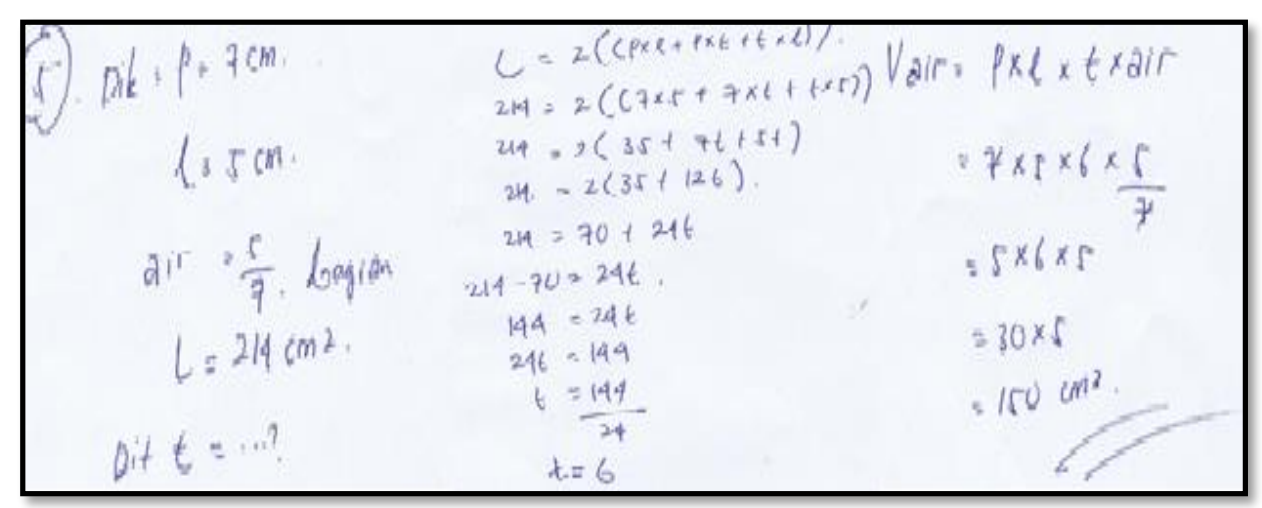

Figure 8.b. FI Student Answers 1 to Problem Number 5 


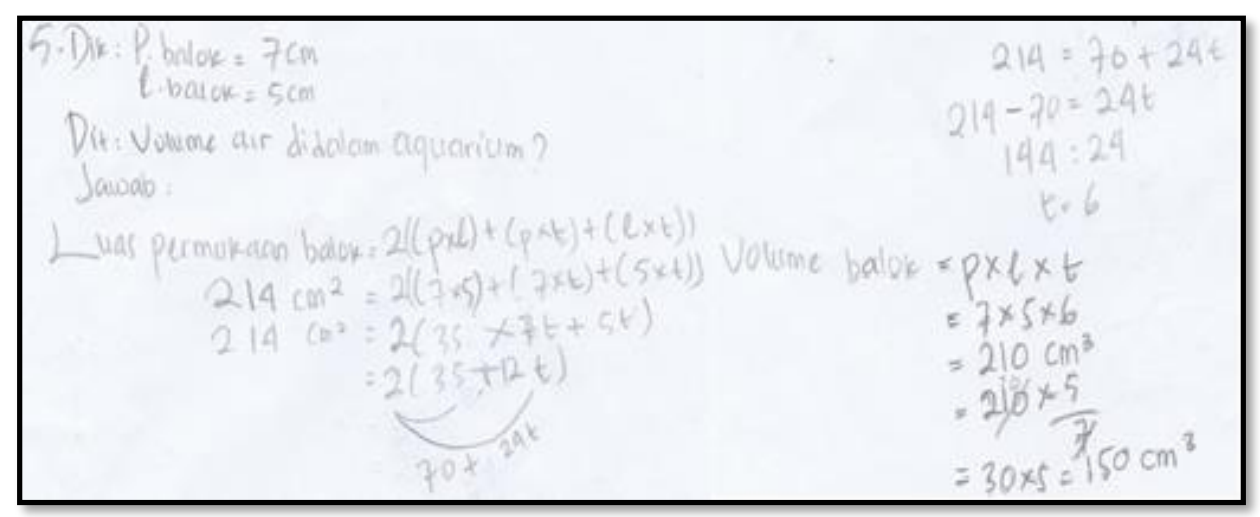

Figure 8.c. FI 2 Student Answers To Problem Number 5

Students with Independent Field cognitive style can apply their understanding of concepts or problem-solving algorithms contained in question number 5. Based on the test results about the ability to understand mathematical concepts and the level of difficulty has been analyzed, it is obtained that the question number 5 was grouped into difficult category. Nevertheless, FI students can solve problem number 5 correctly. FI students analyzed question number 5 and conducted experiments to obtain the right answer. Thus, students with Independent Field cognitive style have good analytical skills.

\section{Discussion}

Based on the results of the study it was found that the ability to understand mathematical concepts in solving the 3D geometry, students with field-dependent cognitive style tend to be inactive, unable to find solutions to existing problems, lack of concentration, lack of confidence in their understanding of concepts, less able in filtering information obtained, less able to associate concepts they understood with real-life concepts, unable to think complexly, tend to think globally, and unable to analyze properly. It is consistent with Hidayat \& Siswono (2016) stating that student with Field Dependent cognitive style tends to be stuck and could not find ideas to solve problems. Furthermore, students with Field Dependent cognitive style had learning concentration problem (Purnomo, Sunardi, \& Sugiarti, 2017). The results of the study are also inline with Azlina, Amin, \& Lukito (2018) an opinion that individual with Field Dependent cognitive style has difficulty in selecting incoming information from their environment and more easily influenced by external factors, that they become less selective in absorbing information. Witkin, Moore, Goodenough, \& Cox (1977) added that students with Field Dependent cognitive style have a tendency to think globally. The results of this study also supported by Ma'rufi, Pasandaran, \& Yogi (2018) showing that the understanding of geometrical concepts by students with a field dependent cognitive style only fulfilled 4 indicators, namely: (a) verbally stating the concepts learned, (b) classifying concepts based on requirements fulfillment, (c) applying the concepts algorithmically, and (d) applying concepts in various forms of representation. An indicator that SFD has not been able to fulfill is to relate various concepts (internal and external mathematics).

On the other hand, students with Independent Field cognitive style can find a solution after remembering the concept they understand, can develop an understanding of the concepts they have, can easily process the information in the question, filter the information available, can relate between concept understanding into the problem with confidence in oneself without being influenced by others and have good analytical skills. It is parallel 
with Hidayat \& Siswono (2016) study stating that student with Independent Field cognitive style tend to stop for a moment and remember the understanding of concepts or mathematical topics related to the problem, so that they can finally find a solution to the problem. Defining that individual with Independent Field cognitive style are able to separate incoming information easier and more easily influenced by internal factors, so that they are more selective in absorbing information. While Witkin et al. (1977) show that students with Independent Field cognitive style were able to use their analytics skills properly. In addition, in understanding geometry concept students with independent field cognitive style can meet the five indicators of understanding the concept, namely (a) verbally stating the concept being studied, (b) classifying the concept based on requirements fulfillment, (c) applying the concept in an algorithmic way, (d) applying concepts in various forms of representation, and (e) linking various concepts (internal and external mathematics) (Ma'rufi et al., 2018).

Furthermore, based on the findings, there are differences between students with Field Dependent cognitive style and those with Independent Field cognitive style in solving 3D geometry problems. Students who have independent field cognitive style have better visual skills than those with field dependent cognitive styles (Yazici, 2016). Singer, Voica, \& Pelczer (2017) the results of his research prove that cognitive style can be a good predictor of students' mathematical creativity. Furthermore, Udiyono \& Yuwono (2018) concluded that cognitive style has positive impacts on the students geometry learning outcomes.

\section{CONCLUSION}

Based on the results and discussion above, it can be concluded that the mathematical comprehension of students with Independent Field cognitive style is better than those of students with Field dependent cognitive style in solving 3D geometry questions. That is because students with Independent Field cognitive style are able to solve questions related to their ability to understand 3D geometry concepts, able to use concepts and problem solving steps appropriately, even confident with their own concepts to produce correct answers. Therefore, in preparing a learning process, a teacher has to take students' cognitive styles into account, that appropriate learning methods and exam questions can be developed for students with different cognitive styles. Students with Field Dependent cognitive style have difficulties when solving 3D geometry problems, difficult to understand geometry concept, can not use the concept and the problem solving steps appropriately, lack of concentration when working on the question, less confident on their comprehension on geometry concepts leading to an incorrect answer

\section{ACKNOWLEDGEMENT}

We thank all those who have helped in the writing of this paper

\section{REFERENCES}

Agoestanto, A., Sukestiyarno, Y., \& Rochmad. (2016). Analysis of mathematics critical thinking students in junior high school based on cognitive style. Journal of Physics: Conf. Series, 824(012052), 1-8. https://doi.org/10.1088/1742-6596/755/1/011001

Ali, A. A., \& Reid, N. (2012). Understanding mathematics: Some key factors. European Journal of Educational Research, 1(3), 283-299. 
Azlina, N., Amin, S. M., \& Lukito, A. (2018). Creativity of field-dependent and fieldindependent students in posing mathematical problems. Journal of Physics: Conf. Series, 947(012031), 1-6.

Broeck, H. Van Den, Vanderheyden, K., \& Cools, E. (2003). Individual Differences in Cognitive Styles: Development, Validation and Cross-Validation of the Cognitive Style Inventory. Vlerick Leuven Gent Working Paper Series.

Gunhan, B. C. (2014). A case study on the investigation of reasoning skills in geometry. South African Journal of Education, 34(2), 1-19.

Hidayat, R., \& Siswono, T. Y. E. (2016). Profil berpikir siswa smp dalam problem posing berdasarkan gaya kognitif field dependent-field independent. Mathedunesa, 3(5), 473-482.

AE. (1999). TIMSS 1999 User Guide for the International. Boston: International Study Center Lynch School of Education Boston College.

IAE. (2004). TIMSS 2003 International Mathematics Report. Boston: TIMSS \& PIRLS International Study Center.

IEA. (2008). TIMSS 2007 International Mathematics Report: Findings from IAE's Trend in International Mathematics and Science Study at the Fourth and Eighth Grades. Boston: TIMSS \& PIRLS Internation Study Center.

IEA. (2011). TIMSS 2011 International Results in Mathematics. Boston: TIMSS \& PIRLS International Study Center.

IAE. (2015). TIMSS 2015 International Results in Mathematics: Fourth Grades Mathematics. Boston: TIMSS \& PIRLS International Study Center.

İbili, E., Çat, M., Resnyansky, D., Şahin, S., \& Billinghurst, M. (2019). An assessment of geometry teaching supported with augmented reality teaching materials to enhance students' 3D geometry thinking skills. International Journal of Mathematical Education in Science and Technology, 50(5), 1464-5211. https://doi.org/10.1080/0020739X.2019.1583382

Karaçam, S. (2015). The effects of field dependent / field independent cognitive styles and motivational styles on students' conceptual understanding about direct current circuits. Asia-Pacific Forum on Science Learning and Teaching, 16(2), 1-19.

Kemendikbud. (2016). Peraturan Menteri Pendidikan dan Kebudayaan nomor 21 Tahun 2016 Tentang Standar Isi Pendidikan Dasar dan Menengah.

Ma'rufi, Pasandaran, R. F., \& Yogi, A. (2018). Pemahaman konsep geometri mahasiswa berdasarkan gaya kognitif mahasiswa. Proxiimal: Jurnal Penelitian Matematika dan Pendidikan Matematika, 1(2), 56-67.

Minarni, A., Napitupulu, E. E., \& Husein, R. (2016). Mathematical understanding and representation ability of public junior high school in North Sumatra. Journal on Mathematics Education, 7(1), 43-56.

NCTM. (2000). Principles and standards for school mathematics. Reston, VA.: National Council of Teachers of Mathematics.

Nuriadin, I., Kusumah, Y. S., Sabandar, J., \& Dahlan, J. A. (2015). Enhancing of students' mathematical reflective thinking ability through knowledge sharing learning strategy in senior high. International Journal of Education and Research, 3(9), 255-268.

Onyekuru, B. U. (2015). Field dependence-field independence cognitive style, gender, career choice and academic achievement of secondary school students in emohua local government area of Rivers State. Journal of Education and Practice, 6(10), 7686.

Purnomo, R. C., Sunardi, \& Sugiarti, T. (2017). Profil kreativitas dalam pemecahan masalah matematika ditinjau dari gaya kognitif field independent (FI) dan field dependent (FD) siswa kelas VIII A SMP Negeri 12 Jember. Jurnal Edukasi, 4(2), 914. 
Riding, R. J., \& Sadler-smith, E. (1997). Cognitive style and learning strategies: Some implications for training design. International Journal of Training and Development, 1(3), 199-208.

Singer, F. M., Voica, C., \& Pelczer, I. (2017). Cognitive styles in posing geometry problems : implications for assessment of mathematical creativity. ZDM Mathematics Education, 49(1), 37-52. https://doi.org/10.1007/s11858-016-0820-x

Sudirman. (2016). Analisis pemahaman konsep himpunan mahasiswa ditinjau dari asal sekolah. Mathline: Jurnal Matematika dan Pendidikan Matematika, 1(1), 43-52.

Sumartini, T. S., \& Priatna, N. (2018). Identify student mathematical understanding ability through direct learning model. Journal of Physics: Conference Series PAPER, 1132(012043), 1-8. https://doi.org/10.1088/1742-6596/1132/1/012043

Udiyono, \& Yuwono, M. R. (2018). The correlation between cognitive style and students' learning achievement on geometry subject. Infinity: Journal of Mathematics Education, 7(1), 35-44. https://doi.org/10.22460/infinity.v7i1.p35-44

Waedi, Winarso, W., \& Izzati, N. (2017). Perbandingan pemahaman konsep matematika siswa ditinjau dari gaya kognitif antara field independent dengan field dependent. Eduma: Jurnal Pendidikan Dan Pembelajaran Matematika, 6(1), 1-7.

Wijayanti, An., Safitri, P. T., \& Raditya, A. (2018). Analisis pemahaman konsep limit ditinjau dari gaya belajar interpersonal. Prima: Jurnal Pendidikan Matematika, 2(2), $157-173$.

Witkin, H. A., Moore, C. A., Goodenough, D., \& Cox, P. W. (1977). Field-dependent and field-independent cognitive styles and their educational implications. Review of Educational Research, 47(1), 1-64. https://doi.org/10.3102/00346543047001001

Yazici, Y. E. (2016). The relationship between cognitive style and visual spatial intelligence of first year architectural students. Kastamonu Ĕ̈itim Dergisi, 25(2), 805-820. 
Sudirman, Son, Rosyadi, \& Fitriani. / Formatif: Jurnal Ilmiah Pendidikan MIPA 10(1), 1-12

This page intentionally left blank 